\title{
The Effect of Tourism Attractiveness and Destination Image on Revisit Intention Through Tourist Satisfaction (Study on Domestic Tourists of Mount Bromo, Malang, East Java)
}

\author{
Raihan Wishal Nafis ${ }^{1 *} \quad$ Sudarmiatin $^{2} \quad$ Sutrisno $^{3}$ \\ 1. State University of Malang. Address: Leses, Ngijo Village, Karangploso District, Malang, East Java Province, \\ Indonesia \\ 2. State University of Malang. Address: Perum Oma View GB-10, Kedungkandang District, Malang, East Java \\ Province, Indonesia \\ 3. State University of Malang. Address: Perum Karanglo Indah W-22, Blimbing District, Malang, East Java
}

Province, Indonesia

\begin{abstract}
Mount Bromo is one of the most famous tourist destination in Indonesia. Many tourist are willing to make revisit to Mount Bromo more than once. This research is quantitative and explains the condition of each variable and the effect of tourism attractiveness variables and destination image on revisit intention with tourist satisfaction as an intervening variable. The population of this study is tourists who visiting Mount Bromo between November 2018 - December 2018, while the samples used were 385 people from visitors to Mount Bromo. The number 385 is obtained after the calculation is done using the Lemeshow formula. The method of collecting data using a questionnaire and using the purposive sampling method. In analyzing data this study uses path analysis. The findings in this research are: (1) Tourism Attractiveness has a positive and significant effect on tourist satisfaction ; (2) Destination image has a positive and significant effect on tourist satisfaction; (3) Tourism attractiveness has a positive and significant effect on revisit intention; (4) Destination image has a positive and significant on revisit intention; (5) Tourist satisfaction has a positive and significant effect on revisit intention; (6) Tourism attractiveness and destination image has a positive and significant effect on tourist satisfaction; (7) Tourism attractiveness and destination image has a positive and significant effect on revisit intention through tourist satisfaction
\end{abstract}

Keywords: Tourism Attractiveness, Destination Image, Revisit Intention, Tourist Satisfaction

DOI: $10.7176 / \mathrm{EJBM} / 11-11-12$

Publication date: April $30^{\text {th }} 2019$

\section{Introduction}

There are many Indonesian people now who like tourism activities as a means to get rid of their fatigue from their daily routine. Many of them are willing to go far out of town just to find good locations as their place of recreation. Tourism according to the Republic of Indonesia Tourism Law Number 10 of 2009 is a variety of tourism activities and is supported by various facilities provided by the community and the government. Tourists will look for destinations that suit with their interests, according to the Directorate General of Government divided into three types, namely: (1) natural tourism; (2) social cultural tourism; and (3) special interest tourism. In tourism there is one thing that is very influential, namely tourism destination. The tourism destination itself has the understanding of being a place that has tourism resources developed so that it has an attraction as a place visited by tourists. Referring to Law No. 10 of 2009 about tourism, it is explained that tourism attractiveness is a tourist target consisting of natural tourist attraction, social cultural tourism attraction, and special interest.

East Java Province especially in Malang has a lot of potential in the tourism sector. The government itself also began to aggressively make a promotion to attract tourists to come to Malang district, because the more tourists who come will make the community income increases, especially those in direct contact with the world of tourism. The presence of tourists will also increase the regional original income of Malang due to the incoming revenue from tourism entrance ticket retribution. The following are data on tourist visits to Malang.

Table 1. Number of Tourist Visiting Malang 2013-2017

\begin{tabular}{cccc}
\hline Year & Domestic Tourist & Foreign Tourist & Total Number of Tourist \\
\hline 2013 & 2.550 .248 & 33.226 & 2.583 .474 \\
\hline 2014 & 3.170 .575 & 80.792 & 3.251 .367 \\
\hline 2015 & 3.561 .221 & 99.873 & 3.661 .094 \\
\hline 2016 & 5.719 .881 & 129.663 & 5.849 .544 \\
\hline 2017 & 6.230 .992 & 150.774 & 6.471 .766 \\
\hline
\end{tabular}

Source: Department of Tourism and Culture of Malang (2018)

$\mathrm{Wu}$ et all (2015) explained that tourism attractiveness and destination image are factors that must be considered in tourism. Revisit intention will be achieved if both of these things are applied properly. Basiya \& 
Rozak (2012) explained that revisit intention is the condition of someone who does some actions within a certain period of time. In addition, Ismayanti (2009) also defines attractiveness as the main factor of tourism in some tourist destination. If tourists feel satisfied with a tourism destination, the intention to revisit will arise. This also means that tourists will revisit the tourist destination and will provide information to other tourists.

Tourists who feel dissatisfied will cause a large potential customer exit that will reduce the number of tourist visits to these tourist destinations. But, if tourists feel satisfied during visiting tours will create a positive image of tourism services. This will ultimately have a significant contribution to the development of the tourism sector in Indonesia. Based on the background that has been explained, the problems in this research are as follows: (1) To find the effect of tourism attractiveness on tourist revisit intention at Mount Bromo; (2) To find the effect of destination image on tourist revisit intention at Mount Bromo; (3) To find the effect of tourism attractiveness on tourist satisfaction at Mount Bromo; (4) To find the effect of destination image on tourists satisfaction at Mount Bromo; (5) To find the effect of tourist satisfaction on tourists revisit intention at Mount Bromo; (6) To find the effect of tourism attractiveness and destination image on tourist satisfacton at Mount Bromo; (7) To find the effect of tourism attractiveness and destination image on tourists revisit intention at Mount Bromo through tourist satisfaction.

\section{Research Methods}

2.1 Search Model and Hypothesis

The study which was made to establish the effect of tourism attractiveness and destination image on revisit intention through tourist satisfaction was carried out according to the search model in figure 1.

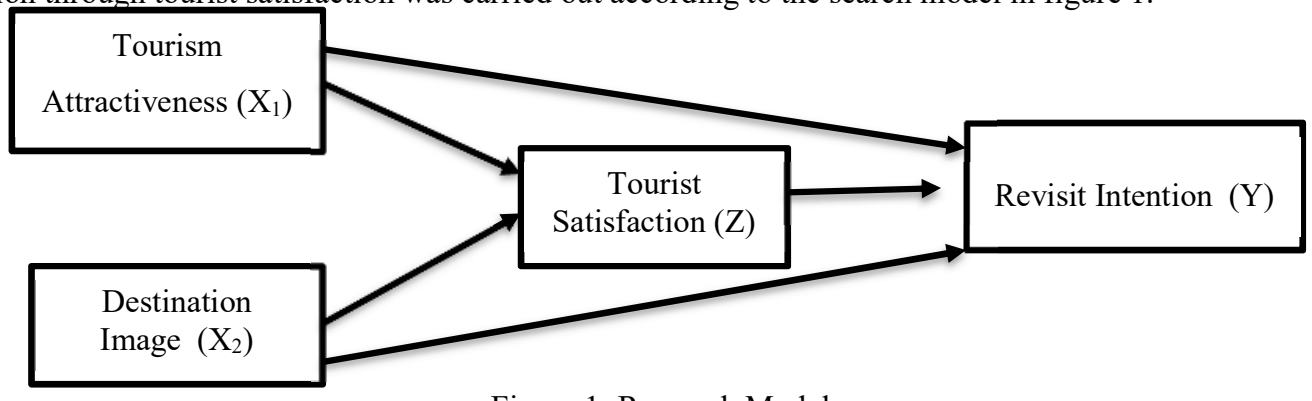

Figure 1: Research Model

Based on existing theories, there are several hypotheses proposed in this study:

H1: Tourism attractiveness has a positive and significant effect on tourist satisfaction

Research conducted by Sopyan \& Widianto (2012) states that tourism attractiveness has a positive effect on tourist satisfaction. In addition, Basiya \& Rozak (2012) also prove that the quality of attractiveness influences satisfaction. The same thing was stated by Aprilia et all (2017) which states that tourism attractiveness has a significant effect on tourist satisfaction. So it can be concluded that tourism attractiveness has a positive effect on tourist satisfaction.

H2: Destination image has a positive and significant effect on tourist satisfaction

Destination image can affect tourist satisfaction and tourist loyalty. Coban (2012) proved in his research that a positive destination image will make tourists feel better satisfaction, and the possibility of being willing to visit again and recommend related destinations to others. Wu et all (2015) also emphasized in his research that destination image has a positive influence on tourist satisfaction. Hanif et al (2016) in their study also found that destination images affect tourist satisfaction, where tourists who have a positive assessment of related tourist destinations, will get high satisfaction.

H3: Tourism attractiveness has a positive and significant effect on revisit intention

Research conducted by Chien (2016) states that tourism attractiveness has a positive effect on revisit intention. In addition, Sopyan \& Widianto (2015) also proved that tourist attraction has a positive effect on revisit intention. The same thing is also evidenced by the research of Basiya \& Rozak (2012) which states that tourism attractiveness has a positive effect on revisit intention. So it can be concluded that tourism attractiveness has a positive effect on revisit intention.

H4: Destination image has a positive and significant effect on revisit intention

Wu et all (2015) in his study proved that destination image has an effect on revisit intention, because a good image can influences the intention to revisit the tourism destination. Hanif et all (2016) in his research also proved that destination image is positively proven to affect tourist loyalty and will positively influence revisit intention.

H5: Tourist satisfaction has a positive and significant effect on revisit intention

Aunalal et all (2017) states that tourist satisfaction has a positive and significant impact on tourist loyalty to a destination. Research conducted by Basiya \& Rozak (2012) states that satisfaction has a positive effect on revisit intention. In addition Sopyan \& Widianto (2013) also states that there is a positive relationship between satisfaction 
and loyalty. Hanif et all (2016) in his study also found that tourist satisfaction has a positive and significant effect on tourist loyalty, satisfied travelers will tend to be loyal to the tourism destinations visited. Travelers who have positive experiences have a greater chance to become loyal tourists and make a revisit intention.

H6: Tourism attractiveness and destination image has a positive and significant effect on tourist satisfaction

Basiya \& Rozak (2012) prove that the tourism attractiveness and supported by destination image will have a positive effect on tourist satisfaction. Hanif et al (2016) in their study also found that destination image influences tourist satisfaction, where tourists who have a positive assessment of the attractiveness of related tourist destinations, will get high satisfaction.

H7: Tourism attractiveness and destination image has a positive and significant effect on revisit intention through tourist satisfaction

Destination image is something that must be continuously conveyed to tourists so that the positive image that has been formed in the minds of tourists will stick to it for a long time. A positive image can encourage someone to be more loyal and willing to make a repeat visit or recommend to others. This has been proven by $\mathrm{Chi} \& \mathrm{Qu}$ (2008) which states that indirectly that tourism attractiveness and destination image can influence revisit intention through tourist satisfaction. Munhurrun et all (2014) also explained that tourism attractiveness and destination image indirectly also affect loyalty variables through tourist satisfaction variables.

\subsection{Data Collecting and Analysis}

The subjects in this study were all domestic tourists who visited Mount Bromo between November 2018 December 2018. The questionnaire was given to respondents who were the research samples that had been determined. The measurement method on the questionnaire uses a Likert scale with five scales. This scale will eventually produce interval data (Cooper \& Schindler, 2014). Based on the main research problems, research objectives, research hypotheses, and research conceptual framework, the analytical method used in this study is path analysis. Hypothesis acceptance criteria is $\mathrm{H}_{0}$ accepted if sig value $>\alpha$ value and vice versa if sig value $<$ value $\alpha$ then $\mathrm{H}_{0}$ is rejected. Ha is accepted if the value is $\operatorname{sig}<$ value $\alpha$ and vice versa if the value of $\operatorname{sig}>$ value $\alpha$ then $\mathrm{Ha}$ is rejected.

\section{Results and Discussion}

3.1 Result of Path Analysis

The output of data processing to determine the effect of tourism attractiveness and destination image on revisit intention through tourist satisfaction are as follows:

Table 2. Path Analysis Result Model 1

Coefficients $^{\mathrm{a}}$

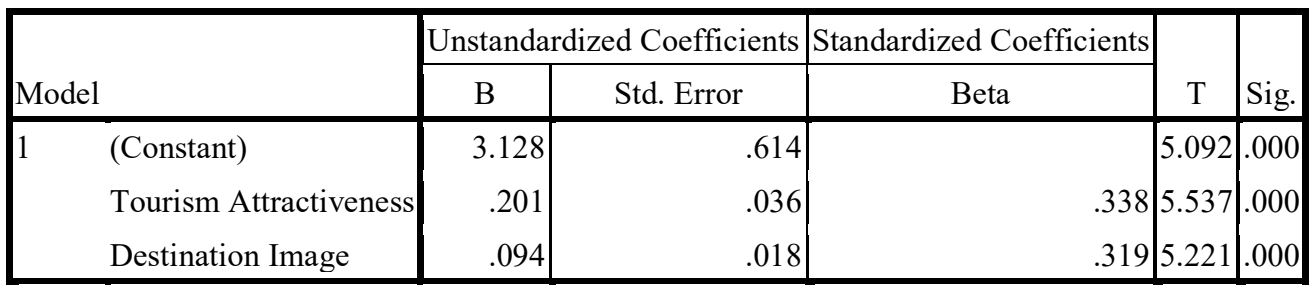

a. Dependent Variable: Tourist Satisfaction

\begin{tabular}{|l|r|r|r|r|}
\hline Model & $\mathrm{R}$ & R Square & Adjusted R Square & Std. Error of the Estimate \\
\hline 1 & $.616^{\mathrm{a}}$ & .379 & .376 & 1.537 \\
\hline
\end{tabular}

a. Predictors: (Constant), Destination Image, Touris

1. Referring to the output results above, in the coefficients table it can be seen that the significance values of the two variables, $X_{1}$ are 0,000 and $X_{2}$ are 0,000 where the significance values of the two variables are smaller than 0.05 . These results provide a conclusion that path analysis model 1 is tourism attractiveness and destination image have a positive effect on tourist satisfaction.

2. The value of the R Square found in the model summary table is 0.379 , this indicates that the contribution or the influence of tourism attractiveness and destination image of tourist satisfaction is $37.9 \%$ while the remaining $62.1 \%$ is a contribution from other variables not included in this research.

3. The value of $e_{1}$ can be searched by the formula $e_{1}=\sqrt{(1-0,379)}$ and the final result is found that is equal to 0,788 
Table 3. Path Analysis Result Model 2

Coefficients $^{\mathrm{a}}$

\begin{tabular}{|l|r|r|r|r|r|}
\hline \multirow{2}{*}{ Model } & \multicolumn{2}{|c|}{ Unstandardized Coefficients } & Standardized Coefficients & \\
\cline { 2 - 5 } & \multicolumn{1}{|c|}{$\mathrm{B}$} & Std. Error & Beta & $\mathrm{t}$ & Sig. \\
\hline 1 (Constant) & 2.725 & .534 & 5.103 & .000 \\
Tourism Attractiveness & .081 & .032 & .143 & 2.564 & .011 \\
Destination Image & .022 & .016 & .080 & 1.432 & .015 \\
Tourist Satisfaction & .550 & .043 & .574 & 12.773 & .000 \\
\hline
\end{tabular}

a. Dependent Variable: Revisit Intention

Model Summary

\begin{tabular}{|l|r|r|r|r|}
\hline Model & \multicolumn{1}{|c|}{$\mathrm{R}$} & \multicolumn{1}{|c|}{ R Square } & Adjusted R Square & Std. Error of the Estimate \\
\hline 1 & $.722^{\mathrm{a}}$ & .522 & .518 & 1.293 \\
\hline
\end{tabular}

a. Predictors: (Constant), Tourist Satisfaction, Destination Image, Tourism Attractiveness

1. Referring to the output results above, in the coefficients table, it can be seen that the significance values of the three variables are tourism attractiveness is 0.011 , destination image is 0.015 , and tourist satisfaction is 0.000 where the significance values of the three variables are smaller than 0.05 . These results provide conclusions that path analysis model 2 namely tourism attractiveness, destination image, and tourist satisfaction has a positive effect on revisit intention.

2. The value of R Square found in the model summary table is 0.522 , this indicates that the contribution or the influence of tourism attractiveness, destination image, and tourist satisfaction towards revisit intention is $52.2 \%$ while the remaining $47.8 \%$ is a contribution from other variables not included in this study.

3. The $e_{2}$ value can be searched by the formula: $e_{1}=\sqrt{(1-0,522)}$ and the final result is found to be 0.691

Based on the discussion above, the regression equation can be formulated as follows:

$$
\begin{gathered}
Z=\beta_{3} X_{1}+\beta_{4} X_{2}+e_{1} \\
\mathbf{Z}=\mathbf{0 , 3 3 8}+\mathbf{0 , 3 1 9}+\mathbf{0 , 7 8 8} \\
Y=\beta_{1} X_{1}+\beta_{2} X_{2}+e_{2} \\
Y=\mathbf{0 , 1 4 3}+\mathbf{0 , 0 8 0}+\mathbf{0 , 6 9 1}
\end{gathered}
$$

From the description above, the results in this study can be described as follows:

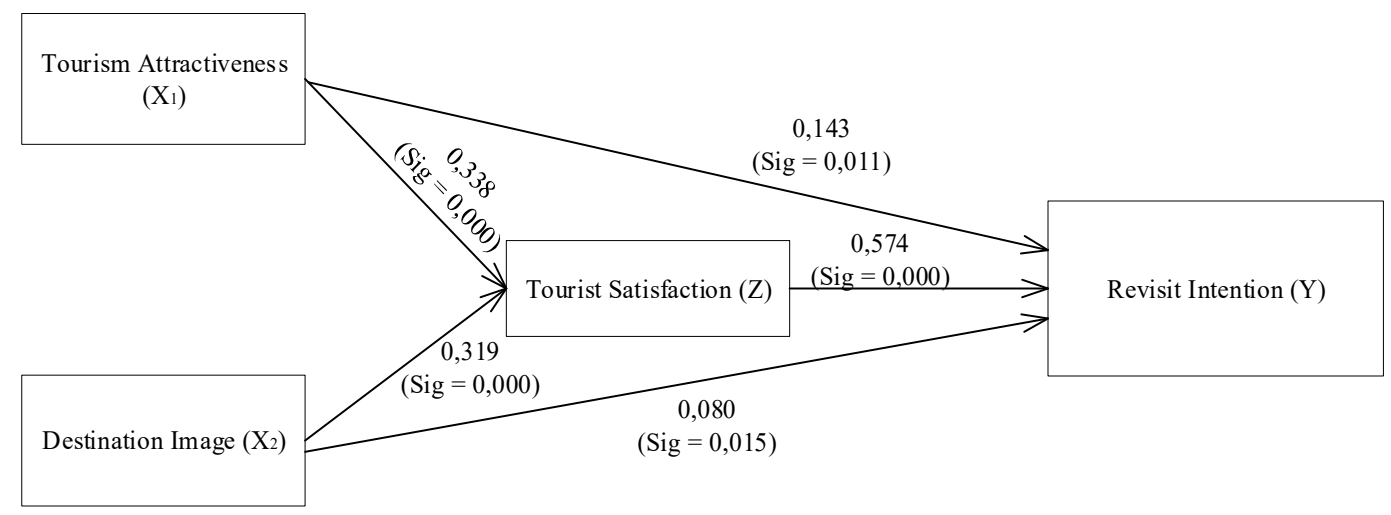

\subsection{Discussion}

The Effect of Tourism Attractiveness on Tourist Satisfaction. Basiya \& Rozak (2012) states that the quality of tourism attractiveness has a positive effect on tourist satisfaction. This opinion is also supported by research from Aprilia et all (2017) which states that tourism attractiveness variables have a significant effect on satisfaction of tourists visiting Balekambang Beach in Malang. This is also in line with previous studies conducted by Sopyan \& Widianto (2012), which state that tourism attractiveness has a significant effect on tourist satisfaction.

The Effect of Destination Image on Tourist Satisfaction. Hanif et all (2016) states that destination image affects tourist satisfaction, where tourists who have a positive assessment of the related destination, will get high 
satisfaction. This opinion is also supported by research from Coban (2012) which states that a positive destination image will make tourists feel better satisfaction, and even likely to recommend these tourist destinations to others. This is also in line with several previous studies conducted by Wu et all (2015) and Sengkaeng et all (2015) which state that destination images have a significant effect on tourist satisfaction.

The Effect of Tourism Attractiveness on Revisit Intention. Chien (2016) states that positive tourism attractiveness according to tourists will have a positive effect on revisit intention. This opinion is also supported by research from Sopyan \& Widianto (2015) which also states that attraction has a positive influence on revisit intention. This is also in line with several previous studies conducted by Okello \& Yerian (2009) and Li et al. (2014) which state that tourist attraction has a significant effect on revisit intention.

The Effect of Destination Image on Revisit Intention. Wu et all (2015) stated that destination image has an effect on revisit intention, because a good destination image can influence the intention of tourists to make a repeat visit. This opinion is also supported by research from Hanif et all (2016) which also states that the destination image is positively proven to be able to influence tourist loyalty and will have a positive effect on revisit intention. This is also in line with previous studies conducted by Samsudin et all (2016) which state that destination images have a significant effect on revisit intention.

The Effect of Tourist Satisfaction on Revisit Intention. Hanif et all (2016) states that tourist satisfaction has a positive and significant effect on tourist loyalty, satisfied tourists will tend to be loyal to the tourism destinations visited. Travelers who have positive experiences have a greater chance to become loyal tourists and revisit intention. This opinion is also supported by research from Aunalal et all (2017) which states that tourist satisfaction has a positive and significant impact on tourist loyalty of a destination, and that loyalty will continue to be a process of repeat visits. This is also in line with several previous studies conducted by Sopyan \& Widianto (2012), Samsudin et all (2016), and Adytia \& Yuniawati (2016) which states that tourist satisfaction has a significant effect on revisit intention.

The Effect of Tourism Attractiveness and Destination Image on Tourist Satisfaction. Sopyan \& Widianto (2012) states that tourism attractiveness and destination image have a positive effect on tourist satisfaction. This opinion is also supported by research from Basiya \& Rozak (2012) which states that tourist attraction has a positive effect on tourist satisfaction, and destination image also has a positive effect on tourist satisfaction.

The Effect of Tourism Attractiveness and Destination Image on Revisit Intention through Tourist Satisfaction. Chi \& Qu (2008) states that tourism attractiveness and destination image can influence tourist satisfaction, then tourist satisfaction also influences the decision of tourists to revisit. So indirectly tourism attractiveness and destination image has a positive influence on interest in revisiting. This opinion is also supported by research from Munhurrun et al (2014) which states that destination images indirectly affect loyalty, where this loyalty will also influence the interest of returning to consumers, the same thing is also conveyed by Ling et all (2010) where the image a destination if it meets a tourism attractiveness will result in a level of satisfaction and will increase the likelihood of visiting again and even giving positive recommendations to others.

\section{Conclusion}

From the results of this research, researchers can draw conclusions as follows: (1) Tourism attractiveness has a positive and significant effect on tourist satisfaction; (2) Destination image has a positive and significant effect on tourist satisfaction; (3) Tourism attractiveness has a positive and significant effect on revisit intention; (4) Destination image has a positive and significant effect on revisit intention; (5) Tourist satisfaction has a positive and significant effect on revisit intention; (6) Tourism attractiveness and destination image has a positive and significant effect on tourist satisfaction; (7) Tourism attractiveness and destination image has a positive and significant effect on revisit intention through tourist satisfaction. From the results of this study, researchers can give the following suggestions: (1) For TNBTS as the administrator of Mount Bromo, TNBTS is expected to be able to increase the tourism attractiveness of Mount Bromo, especially about the naturalness of Mount Bromo, alternative tourism in the area around Mount Bromo, as well as repairs to public facilities and road access. In addition, TNBTS is also expected to maintain the consistency of tourism attractiveness that are considered the most positive by tourists, namely the scarcity or uniqueness of Mount Bromo that is not elsewhere. TNBTS is also expected to be able to improve the destination image of Mount Bromo, especially regarding a safe and pollutionfree tourist environment, preserving wild life $1 \mathrm{t}$ is in the area around Mount Bromo, maintaining the distinctive culture of the Tengger people around Mount Bromo, and adding supporting infrastructure such as places to buy souvenirs and places to buy food. In addition, TNBTS is also expected to maintain the consistency of the destination image that is considered the most positive by tourists, namely the matter of the price of accommodation and entrance tickets that tourists consider still in accordance with their abilities; (2) For Tourists, tourists are expected to be able to manage and become smart tourists by considering every aspect before visiting tourist destination So that tourists will feel really satisfied after making a tourist visit, the positive impact that will be felt later is that tourists will have the desire to re-visit the tourist destination. The negative impact caused by poor management is that tourists will be wasteful. 
References

Adytia, C.A., \& Yuniawati, Y (2016), “The Effect of Customer Experience on Revisit Intention at The Trans Luxury Hotel Bandung (Study on Tourists as a Individual First Timer Guest The Trans Luxury Hotel Bandung)", Journal Tourism And Hospitality Essentials, Vol.5, No.1

Aprilia, E.R., Sunarti., Pangestuti, E (2017), "Pengaruh Daya Tarik Wisata dan Fasilitas Layanan Terhadap Kepuasan Wisatawan di Pantai Balekambang Kabupaten Malang”, Jurnal Bisnis dan Manajemen

Aunalal, Z.I (2017), “The Influence of Service Quality Dimentions, Destination Image and Satisfaction to Tourist Loyalty in Maluku Province", Jurnal Bisnis dan Manajemen

Basiya, R., \& Rozak, H.A (2012), “Kualitas Daya Tarik Wisata, Kepuasan dan Niat Kunjungan Kembali Wisatawan Mancanegara di Jawa Tengah", Jurnal Ilmiah Dinamika Kepariwisataan, Vol.11, No.2

Chi, C. G. Q., Qu, H (2008), "Examining the Structural Relationships of Destination Image, Tourist Satisfaction and Destination Loyalty: An Integrated Approach", Journal Tourism Management, Vol.29, No.4, pp.624-636

Chien, M.C (2016), “An Empirical Study On The Attractiveness of Ecotourism Destination Value and Revisit Intention", Journal Tourism Management

Coban, S (2012), "The Effect of the Image of Destination on Tourist Satisfaction and Loyalty: The Case of Cappadocia", Journal Tourism Management

Cooper, D.R., \& Schindler, P.A (2014), Business Research Metehods. New York, McGraw-Hill

Department of Tourism and Culture of Malang (2018), "The Number of Tourists Who Visit Malang 2013-2017"

Hanif, A., Kusumawati, A., Mawardi, M.K (2016), "Pengaruh Citra Destinasi Terhadap Kepuasan Wisatawan Serta Dampaknya Terhadap Loyalitas Wisatawan (Studi Pada Wisatawan Nusantara yang Berkunjung ke Kota Batu)", Jurnal Administrasi Bisnis (JAB), Vol.38, No.1

Ismayanti (2009), Pengantar Pariwisata. Jakarta, PT Gramedia Widiasarana Indonesia

Li, L., Yuan, S.M., Jiang, N (2014), “An Analysis Of The Influencing Factors Of Customer Retention In Tourism Resort Industry: A Case Study Of Lingnan Impression Park, Guangzhou, China", Eurasian Journal of Business And Management, Vol.2, No.2

Ling, L.Q., Karim, M.S.H., Otman, M., Adzhan, N.M., Ramachandaran (2010), "Relationships Between Malaysian Food Image, Tourist Satisfaction and Behavioral Intention”, World Applied Sciences Journal 10 (Special Issue of Tourism \& Hospitality), pp.164-171

Munhurrun, P.T, Seebaluck, V.N., Naido, P (2014), “Examining The Structural Relationship of Destination Image, Perceived Value, Tourist Satisfaction and Loyalty: Case of Mauritius", Journal Tourism Management

Okello, M.M., \& Yerian, S (2009), "Tourist Satisfaction In Relation To Attractions And Implications For Conservation In The Protected Areas Of The Northern Circuit, Tanzania", Journal Of Sustainable Tourism, Vol.17, No.5

Samsudin, A., Saerang, D.P.E., Worang, F.G (2016), “Analysing The Effects Of Destination Image And Tourist Satisfaction On Revisit Intention In Case Bunaken National Park", Jurnal Berkala Ilmiah Efisiensi, Vol.16, No.4

Sengkaeng, S., Mananeke, L., Orah, S.G (2015), "Pengaruh Citra, Promosi Dan Kualitas Pelayanan Objek Wisata Terhadap Kepuasan Wisatawan Di Objek Wisata Taman Laut Bunaken Sulawesi Utara", Jurnal EMBA, Vol.3, No.3

Sopyan \& Widianto, I (2015), “Anteseden Minat Berkunjung Ulang”, Jurnal Bisnis dan Manajemen

Suradnya, I.M (2005), “Analisis Faktor-Faktor Daya Tarik Wisata Bali Dan Implikasinya Terhadap Perencanaan Pariwisata Daerah Bali", Journal SOCA

Wu, H.C., Ai, C.H., Yang, L.J., Li, T (2015), “A Study of Revisit Intentions, Customer Satisfaction, Corporate Image, Emotions and Service Quality in the Hot Spring Industry", Journal of China Tourism Research 